\title{
Teachers Develop CLIL Materials in Argentina: A Workshop Experience
}

Darío Luis BANEGAS*

\begin{abstract}
Content and language integrated learning (CLIL) is a Europe-born approach. Nevertheless, CLIL as a language learning approach has been implemented in Latin America in different ways and models: content-driven models and language-driven models. As regards the latter, new school curricula demand that CLIL be used in secondary education in Argentina and that teacher pedagogies and materials match the L1 curriculum and overall context. Therefore, teachers initially educated in other paradigms need professional development opportunities to understand CLIL as an innovative language teaching approach. The aim of this article is to reflect on CLIL materials produced by a group of Argentinian teachers as part of a professional development workshop. In this article, I shall first conceptualize CLIL and review the literature around CLIL materials. Then, I describe the workshop and offer content analysis of participants' lesson plans. I shall conclude with emergent working principles based on these participants' practices and suggestions for further research.
\end{abstract}

Keywords: CLIL; materials; materials development; scaffolding; context-responsive materials.

\footnotetext{
* Warwick University, Coventry, UK \& Ministerio de Educación del Chubut, Argentina. Corresponding author: d.banegas@warwick.ac.uk
} 


\title{
Los docentes desarrollan materiales de AICLE en Argentina: una experiencia-taller
}

\begin{abstract}
Resumen
El AICLE es un enfoque que nació en Europa; sin embargo, el AICLE como enfoque para el aprendizaje de lenguas ha sido implementado en Latinoamérica a través de diferentes maneras y modelos: modelos enfocados en contenidos y modelos enfocados en la lengua. En referencia a estos últimos, los nuevos diseños curriculares argentinos esperan que el CLIL sea empleado en la educación secundaria y que las pedagogías docentes y materiales reflejen el contenido curricular y el contexto total. En consecuencia, los docentes entrenados en otros paradigmas necesitan oportunidades de desarrollo profesional que les permitan entender el AICLE como un enfoque innovador para la enseñanza de la lengua. El objetivo de este artículo es reflexionar sobre los materiales para el AICLE desarrollados por un grupo de docentes argentinos como parte de un taller de desarrollo profesional. En este texto se conceptualiza sobre el AICLE y se revisa la literatura correspondiente. También, se describe el taller en cuestión y se ofrece un análisis de las secuencias y los materiales de los docentes participantes; finalmente, se concluye con los principios de trabajo emergentes de los trabajos de los participantes y son sugeridas rutas para investigaciones futuras.
\end{abstract}

Palabras claves: AICLE; materiales; desarrollo de materiales; andamiaje; materiales contextualizados. 


\title{
Desenvolvimento de materiais de Aprendizagem Integrada de Conteúdos e de Língua na Argentina: experiência de uma oficina
}

\begin{abstract}
Resumo
A Aprendizagem Integrada de Conteúdos e de Língua (AICL) é uma abordagem que nasceu na Europa e, na América Latina, tem sido implantada de diferentes maneiras e modelos: modelos enfocados em conteúdos e modelos enfocados na língua. A respeito deste último, os novos desenhos curriculares argentinos esperam que a AICL seja empregada no ensino médio e que as pedagogias docentes e materiais reflitam o conteúdo curricular e o contexto total. Em consequência, os docentes capacitados em outros paradigmas precisam de oportunidades de desenvolvimento profissional que lhes permitam entender a AICL como uma abordagem inovadora para o ensino de língua. O objetivo deste artigo é refletir sobre os materiais para a AICL desenvolvidos por um grupo de docentes argentinos como parte de uma oficina de desenvolvimento profissional. Neste artigo, conceitua-se a AICL e revisa-se a literatura correspondente. Além disso, descreve-se a oficina em questão e oferece-se uma análise das sequências e dos materiais dos docentes participantes. Finalmente, conclui-se com os princípios de trabalho emergentes dos trabalhos dos participantes e sugerem-se caminhos para pesquisas futuras.
\end{abstract}

Palavras-chave: AICL; materiais; desenvolvimento de materiais; arcabouço linguístico; materiais contextualizados. 


\section{INTRODUCTION}

Materials development in foreign language teaching is an area richly examined in the literature from perspectives such as design, implementation, ideologies, and contexts of production and circulation (see Garton \& Graves, 2014; Gray, 2013; McGrath, 2013; Tomlinson, 2013). In Latin America, reports on materials development are also frequent in different fora (see Banegas, 2013a; Barboni \& Simón, 2013; López Barrios et al., 2008; Moirano, 2012).

This article reflects on the CLIL (content and language integrated learning) materials produced by a group of Argentinian teachers as part of a professional development workshop. I first provide an abbreviated stateof-the-art view of CLIL. Secondly, I offer a brief account of CLIL materials with an emphasis on teachers' involvement. Third, I describe a workshop I delivered at the Universidad Nacional de La Pampa (Santa Rosa, Argentina) as part of a programme aimed at in-service teacher development in response to new curricular guidelines in the province of La Pampa, Argentina (Braun, Cabral \& Cheme Arriaga, 2013). Lastly, I analyse samples of materials produced by some of the teachers who attended this workshop.

\section{DEFINING CLIL}

CLIL first appeared in the early 1990s as a 'pragmatic European solution to a European need' (Marsh, 2002, p. 11); that is, pluringualism for market, academic, and social mobility. However, CLIL is not only circumscribed to Europe (see Pérez Cañado, 2011; Ruiz de Zarobe and Cenoz, 2015) since it is also found in Africa (see Gustaffson, 2011), Asia (e.g Lin, 2015; Robertson \& Adamson, 2013) and Latin America (see Banegas, 2013b; Mariño Avila, 2014).

CLIL can be generally defined as a 'dual-focused, learning and teaching approach in which a non-language subject is taught through a foreign language, with the dual focus being on acquiring subject knowledge and competences as well as skills and competences in the foreign language' (Ioannou Georgiu, 2012, p. 495; see also Coyle, Hood, \& Marsh, 2010; Ruiz de Zarobe, 2013). Such a definition can be interpreted through models that range from bilingual education to project work. In Spain, for example, CLIL is realised through the delivery of a part of the school curriculum in anoth- 
er language. Conversely, in Latin America, CLIL is sometimes introduced in the English language classroom by dealing with curricular contents. While the former type of implementation is usually in the hands of a non-foreign language teacher, the latter is delivered by the foreign language teacher (for CLIL in primary education, see Braun \& Cheme Arriaga, 2011).

Due to this multiplicity of interpretations, CLIL is also referred to as an 'umbrella term', but this conceptualisation has generated controversies as researchers highlight the lack of conceptual clarity (Cenoz et al., 2013). Consequently, there have been attempts to distinguish CLIL from its counterpart in Canada and the USA, CBI (content-based instruction), and from immersion education (Cenoz et al., 2013). However, similarities between CBI and CLIL, and the fuzzy line between CLIL and immersion, have been lately discussed (Banegas, 2012; Cenoz, 2015; Cenoz et al., 2013; Somers \& Surmont, 2012). More recently, some authors have stressed the content side of CLIL (see Llinares et al., 2012), but there is wide recognition that although the research reports on language gains realized through CLIL, little has been said about content learning. With regard to languages, Dalton-Puffer (2011) signals that no matter the focus, English is the dominant language in CLIL implementation-with a few exceptions, such as Basque or Spanish.

Cenoz (2013a, 2013b) makes the case that CLIL definitions and international implementations are an invitation to examine whether CLIL is taken as a foreign language approach or a broader educational approach. In addition, the more CLIL is defined, the more it may be isolated from related approaches that also aim at multilingualism. Therefore, integration as opposed to isolation is suggested in order to benefit from research that originates from similar traditions.

How CLIL, whether envisaged as a foreign language or educational approach, will develop is not clear. Policy makers and practitioners adapt it in order to respond to their contextual needs and resources. It is in this direction that future CLIL research should move: How does CLIL impact on different contexts and stakeholders' identities? Is CLIL only successful with selective groups and proficient L2 users? (But see Denman et al., 2013.) Are subject and foreign language teachers qualified to teach both content and language? Are there suitable materials for CLIL? The subsequent CLIL materials section addresses this last question. 


\section{CLIL MATERIALS}

CLIL pedagogies, models, and materials rest on sociocultural pillars. Concepts such as scaffolding, zone of proximal development, and mediation signal that CLIL stresses the need to construct knowledge socially through tools that help learners develop their language competence and non-language content knowledge. In addition, CLIL is also supported by cognitivist views, as CLIL lessons and materials are expected to evolve from lower-order thinking skills, such as describing, to higher-order thinking skills, such as evaluating (see Banegas, 2012).

One of the challenges — but, at the same time, opportunities — of CLIL is the limited number of context-responsive materials available. The literature, however, does offer lists of criteria to follow in order to increase resources for teachers. For example, Mehisto (2012) has produced a list of ten criteria:

1. Make the learning intentions (language, content, learning skills) and process visible to students.

2. Systematically foster academic language proficiency.

3. Foster learning skills development and learner autonomy.

4. Include self, peer and other types of formative assessment.

5. Help create a safe learning environment.

6. Foster cooperative learning.

7. Seek ways of incorporating authentic language and authentic language use.

8. Foster critical thinking.

9. Foster cognitive fluency through scaffolding of a) content, b) language, c) learning skills development helping student to reach well beyond what they could do on their own.

10. Help make learning meaningful.

Readers may notice that such criteria are not truly CLIL-specific; in other words, these suggestions could be useful for any type of approach within and beyond foreign language learning. Nevertheless, Mehisto seems to acknowledge the importance that a sociocultural and sociocognitive perspective exercises on CLIL. 
Morton (2013) discusses CLIL materials based on a group of European teachers' practices and perspectives. In his contribution, he defines CLIL materials as:

Any L2 texts used for the teaching of non-language subject matter, presented to the students in paper-based and/or digital form, and the tasks and activities built around them. (2013, p. 115).

Morton's definition stresses the content component of CLIL but also recognises that materials involve sources of input either in physical or digital format and activities based on these. He moves on to suggest that teachers who cannot use commercial materials for different reasons can produce their own materials (sources and activities), use authentic materials without any modifications, or adapt authentic materials to respond to their settings. Adaptation does not only mean simplification; it also includes elaboration and discursification (Moore \& Lorenzo, 2007).

According to Morton (2013), a key question is how to ensure that materials provide opportunities for both language learning and content learning. He proposes a set of can-do statements, emphasizing that CLIL materials:

- can avoid underestimating learners linguistically and cognitively, by, for example, not treating linguistically low level learners as cognitively low level learners;

- include listening and reading activities that are not used to teach language features but are content meaning focused;

- can avoid the use of bland, safe and harmonious texts by engaging students affectively and intellectually with stimulating texts relating to aspects of content;

- can involve learners in activities in which they cognitively engage with conceptual content, thus enabling them to use the full resources of the brain. (Morton, 2013, pp. 120-121) 
Through a survey that Morton administered to 52 CLIL teachers, he found that they tended not to use materials (e.g. textbooks) designed for native speakers, as they were aware of the mismatch between the materials' underlying curriculum and teachers' curriculum. Nearly $50 \%$ of the teachers reported adapting authentic non-textbook materials and 90\% answered that they produced their own materials from scratch. Reasons for such practices included appropriateness of language and content for learners, appropriateness for educational and cultural context, flexibility, design and pedagogic approach, and availability and convenience.

Based on a collaborative experience of teacher-developed CLIL materials, Banegas (2013c) considers that one of the advantages of teachers adapting or devising CLIL materials is that coherence may be easily achieved, as it derives from possible areas of content such as academic subjects or learner-contributed content. Furthermore, flexibility may be sought through the negotiation of these contents and the freedom to start with any given unit of work. However, due to the nature of this flexible approach, principles such as sequencing and evolving complexity may be affected, as the sequence of contents could be arbitrary. In relation to this, I believe that teachers can reduce this tension if they think of developing materials as building blocks that, when assembled, fulfil the overall aims of a given course. Differently put, each block, with its specific set of subject-related contents, would follow the principles listed above. Teachers might start with any given block, since any of them, whatever the sequence, would contribute to the main aims established.

\section{METHOD}

Forty-five (45) participants attended a workshop titled "Developing materials for CLIL", part of a series of workshops organised by the Universidad Nacional de La Pampa (as mentioned in the Introduction). The workshop consisted of two main parts: 1) an introduction to CLIL, and 2) frameworks for developing CLIL. Overall, 31 lesson plans were submitted in the context of the workshop. Thirty (30) of them obtained a passing mark and only one pair of teachers was asked to resubmit their plans based on the feedback received from the author of this paper. 
In the first part of the workshop, the participants watched a video (UTV Motion Pictures, 2012) and were asked to discuss how such a resource could be used to integrate language and content learning. Based on their contributions, I introduced definitions of CLIL, followed by its theoretical underpinnings (for a recent summary, see Ruiz de Zarobe \& Cenoz, 2015). Based on recent CLIL literature (Coyle et al., 2010; Mehisto et al., 2008), such underpinnings included sociocultural theory, Bloom's revised taxonomy of thinking skills, Cummins' BICS and CALP, autonomy, authenticity and motivation, and different CLIL models placed along a CLIL continuum.

In the second part of the workshop, we discussed and explored different working frameworks for developing CLIL lessons. In this regard, we agreed that our lessons should move from familiar language and familiar content to new content and new language. We also agreed that our activities should consider the language triptych (Coyle et al., 2010, p. 36) to ensure that learners had opportunities to explore the language of/for/ through learning in a lesson. In relation to activities, we discussed the value of graphic organisers and the use of L1 (Spanish, in this context) as another scaffolding tool (Lin, 2015). Finally, in groups, the participants drafted a lesson plan together with activities and materials. This lesson plan was to be assessed in order to pass each workshop of this in-service teacher development programme.

I based the lesson plan analysis on content analysis (Mayring, 2000). My content analysis specifically centred on the materials found in 32 lesson plans: sources of input and activities in relation to the topics selected. Categorisation was based on the concepts introduced in the workshop. Nonetheless, there was room for the inclusion of emergent categories from the data under analysis.

\section{RESULTS}

\section{Teacher-developed materials: topics and sources}

As part of the workshop, teachers were required to submit a language-driven CLIL lesson plan. The teachers were free to select the contents and aims of their lesson and could make use of any available materials. They could also work in pairs or small groups. 
In relation to content and language learning, Table 1 condenses teachers' choices.

\section{Table 1. Teachers' selected content and language items}

\begin{tabular}{|l|l|}
\hline Content learning & $\begin{array}{l}\text { Government. Road safety and rules. Museums. Temperatures. } \\
\text { US independence. Abraham Lincoln. Discrimination and slavery. } \\
\text { Inventions. Teenage health. Natural disasters. Rainforests. Chil- } \\
\text { dren's rights. WWII. French Revolution. Marijuana. }\end{array}$ \\
\hline Language learning & $\begin{array}{l}\text { Regular and irregular verbs. Simple past and past continu- } \\
\text { ous. Present simple. Passive voice. Discourse markers. Modal } \\
\text { verbs. Describing and narrating. Giving opinions. Subject-spe- } \\
\text { cific vocabulary. }\end{array}$ \\
\hline
\end{tabular}

Readers will notice that content items correspond broadly to content subjects such as history, biology, geography, and citizenship. Such subjects and topics are present in the official curricula in Argentina. This shows that teachers can make use of a wide variety of curriculum-related contents that they can accommodate to meet the motivations, needs, and possibilities in their contexts.

In relation to language, the selected language items attest to three main areas of interest or concern: 1) grammar (e.g. passive voice) and textual grammar (e.g. discourse markers), 2) functions (e.g. describing and narrating), and 3) lexis.

In terms of the sources of input chosen, I categorised these according to agency: 1) sources developed or modified by teachers, and 2) sources used as found regardless of their level of authenticity. Table 2 summarises the sources of input that teachers selected.

Table 2 shows that teachers from this group seemed to favour written input and learners' reading skills and the development of oral skills through the deployment of visual aids to scaffold participation. In addition, we should notice that the mainstream course-book adopted from the beginning of the school year was retained for use. Some of the lesson plans were still built around teachers' adopted course-book. However, they selected sections that responded to the content topic and the language 
Table 2. Teachers' sources of input

\begin{tabular}{|c|c|c|}
\hline \multirow{2}{*}{$\begin{array}{c}\text { Teacher-developed } \\
\text { sources }\end{array}$} & Visual & Prezi presentation \\
\hline & Written & Simplified texts \\
\hline \multirow{3}{*}{$\begin{array}{l}\text { Other-developed } \\
\text { sources (authentic } \\
\text { and ELT materials) }\end{array}$} & Visual & $\begin{array}{l}\text { Pictures } \\
\text { Diagrams }\end{array}$ \\
\hline & Audiovisual & $\begin{array}{l}\text { Film trailers } \\
\text { Animated films }\end{array}$ \\
\hline & Written & $\begin{array}{l}\text { General English coursebooks } \\
\text { Wikipedia texts } \\
\text { Webpage articles and posts } \\
\text { Newspaper articles (Buenos Aires Herald, } \\
\text { The New York Times) }\end{array}$ \\
\hline
\end{tabular}

under focus. This seems to contradict the findings from Morton's (2013) survey. One plausible reason for such a difference may be due to the fact that CLIL was envisaged as language-driven, rather than content-driven, as in Morton's study.

\section{Teacher-developed materials: activities}

With regard to activities, teachers did not depart from the typical kinds of activities featured in ELT course-books. In some cases, they used sources and activities found in course-books. However, they did include the use of pictures for labelling and graphic organisers for summarising or comparing and contrasting information. In many lesson plans, learners were asked to complete charts, tables, and timelines.

At the level of skills development, teachers attempted to offer balanced lesson plans even when their main sources of input signalled a preference for written skills. For example, written skills were encouraged through activities such as "read and complete", "read and label a picture", or "write sentences based on cues". On the other hand, oral skills were represented through activities such as "listen and tick the information you hear", "watch and answer", "survey: ask your peers ...", and "present survey results aided by a PowerPoint presentation". 
Some of the teachers included their own developed activities based on different sources of input. In the subsequent Samples (1-5), I offer examples and brief analyses of such activities.

\section{Sample 1}

As the final task of the class I will ask my students to summarize in a graphic organizer the characteristics of rainforests. They will find the information in the texts we've worked with so far.

\begin{tabular}{|l|c|}
\hline & RAINFORESTS \\
\hline TYPES & \\
\hline LAYERS & \\
\hline ANIMALS & \\
\hline
\end{tabular}

In Sample 1, the teacher had previously provided learners with texts taken from a general ELT course-book. However, the activity to be developed aimed at presenting an integrated view of the content addressed. To this effect, the activity also made use of a graphic organiser. Learners were able to focus on content without the pressure of elaborating complex stretches of discourse. Elsewhere, the teacher clarified that the task could be completed in pairs, thus encouraging collaborative learning for the development of writing and summarising skills.

\section{Sample 2}

DRAMA (last activity of a lesson on children's rights)

Teachers will divide the class into two teams (A \& B) and give "RIGHT CARDS" turned face downwards. A player from one of the teams will select a "RIGHT CARD" from the pile and try to act out that right without any verbal clues. The player's team will try to guess what right is being shown (within a time limit).The next team will repeat the process. The team to identify the most rights correctly wins the game. 
Sample 2 shows an activity designed by two teachers based on cards they developed themselves. The activity sought to encourage speaking skills together with identifying and remembering children's rights, promoting interaction and negotiation through roleplaying.

\section{Sample 3}

5. Read the text following the link and decide if the statements are True or False.

http://www.buenosairesherald.com/article/127803/la-plata-remainsunder-water-as-death-toll-climbs-to-48
a) The heavy rains started on Tuesday night.
b) President CFK was born in the city of Buenos Aires.
c) She met Governor Scioli to find a solution to the problems.
d) More than 100 people died because of the floods.
e) Some people got trapped in their cars.

6. This is what a resident told the journalist in the street. Complete the dialogue using past simple or past continuous.

J:Here's Mario, a neighbour from La Plata who's lost everything he had. What were you doing when the heavy rain started?

R: Well, I (watch) TV when it all (start), I ........................... (can) believe it!

$\mathrm{J}$ : And what time the rainpour ... (begin)?

R:I'm not certain about it. I think it ...(begin) late in the afternoon. [the dialogue continues].

The activities presented in Sample 3 attest to the teacher's interest in using an authentic source, coupled with a simple reading comprehension activity. What is worth noticing is that the follow-up activity maintained the same topic: the 2013 flood in the city of La Plata (Argentina), but placed the focus on language development (in this case, past tenses). Such coherence in terms of CLIL lesson planning signals the need to maintain the same topic throughout the plan even at the stage of language practice. 


\section{Sample 4}

3. You are going to watch a video about Magellan's voyage round the world. http://www.youtube.com/watch?v=oSVJKXCLooE Match the dates with the name of the places Magellan and his men reached during his voyage.
1) September 20,1519
left Spain
2) November 27,1519
crossed the Equator
3) December 6, 1519
Got to Cape Verde
4) January 10,1520
Reached Guam and Marianas
5) March 30,1520
Reached Spice Island
6) October 21,1520
Arrived in Cape Virgenes
7) November 1,1520
Got to Rio de la Plata
8) November 28,1520
Entered the South Pacific
9) March 6, 1521
Navigated the Straits of Magellan
10) March 16, 1521
Reached The Philippines
11) June 21, 1521
Reached Brunei
12) November 16,1521
Arrived at Puerto San Julian
13) May 61522
Arrived in Cape of Good Hope
14) July 9,1522
Reached Rio de Janeiro
15) September 6,1522
Arrived in Spain

Similarly to Sample 3, Sample 4 shows the use of an authentic source of input. Although the video was essentially a reading text, it was enhanced through animation, thus becoming a multimodal resource. The teacher developed an activity that allowed learners to practise dates and the simple past tense, but framed in a historical context (in this case, Magellan's voyages). Readers may feel that the activity contains too many items to match; however, this can be addressed by adding more examples before starting or by asking different groups of learners to complete items 1 to 7 and 8 to 15 .

In Sample 5, the teacher developed their own source of input: a reading text that lent itself to an activity in which learners were required to arrange the cut-outs by paying attention to cohesive markers. The activity promoted reading but also offered content based on learners' previous knowledge. It may also be noticed that it tries to support intercultural awareness by providing information about learner's own country. 


\section{Sample 5}

I will ask the students if they know when the gauchos' lifestyle is celebrated in our country. Then, I will give the students a description of the Tradition Day cut into pieces so the students will have to put them in the correct order. I will also explain that the all the paragraphs refer to the description of the Tradition Day celebrated on November 1oth. I will ask students to read the different sentences and I will make sure they understand the new vocabulary (e.g. parades, horseman). After that, students (in pairs) will put the ideas in order taking into account the concepts of coherence and cohesion.

1. The Tradition Day (Día de la Tradición) is celebrated, in my country (Argentina), on November 1oth in commemoration of the poet José Hernandez's birth date, who wrote Martin Fierro, a traditional gaucho song (payada).

2. People, from different towns along Argentina, usually participate in big gaucho parades, parties (known as peñas), concerts where they listen to some folk music and dance. They also celebrate with several acts, such as asados, tamings, different races, among others.

3. On the November 1oth people dress in their best gaucho clothes and go to the peñas. They dance, eat typical Argentine meals like locro or empanadas and have fun. In the evening there is a criollo horsemanship show and a rodeo. They listen to many singers (payadores) reciting and /or singing along the streets. People also stand and watch the parades or they join a fogón where musicians tune their guitars until well after midnight.

4. The Tradition Day is a wonderful national holiday. Everyone has fun and really enjoys themselves. It's a special celebration no one should miss because it's one of the most beautiful and popular traditions of Argentina.

Overall, the five Samples above illustrate ways that teachers can develop their own materials in order to respond to both aspects of CLIL: content and language. In so doing, teachers need to ensure that the activities and overall lessons match their learners' language development needs and scaffold further language and cognitive development.

Furthermore, these activities, as recommended by Mehisto (2012), promote: 
- Cooperative learning.

- Skills development.

- Holistic learning.

Through these features, a socioconstructivist approach emerges, and varied scaffolding tools are incorporated in the process of CLIL materials development. When teachers develop language-driven CLIL materials, the following working principles appear:

- Inclusion of multimodal sources.

- Text simplification.

- Text enhancement through the inclusion of visual support.

- Knowledge structuring through graphic organisers.

- $\quad$ Promotion of cooperative learning strategies.

- $\quad$ Focus on lower-order thinking skills.

\section{DISCUSSION}

Although this experience is limited in terms of its time frame and the number of participants, it may serve as an exploration of how teachers enact and actualise CLIL through context-responsive materials development. In some educational systems, CLIL has been implemented as a foreign-language teaching approach (Cenoz, 2013a) through top-down official curricula. This has led to the development of in-service professional development opportunities that provide practicing teachers with CLIL rationale and practices.

If the market does not offer context-responsive materials for teachers who wish to integrate curricular content in their English language lessons, then teachers can become active agents of change in this regard and work towards the development of CLIL materials. Although teacher-developed CLIL materials can be time consuming and challenging to produce, collaborative work can reduce the load and become a way of sharing materials, practices, and experiences. In so doing, teachers can explore new avenues for professional development and reflect on CLIL principles and CLIL enactment according to curricular demands and local needs and opportunities.

In light of this experience, future research should investigate CLIL professional development opportunities and the dialogue between such 
opportunities and teachers' understanding and practices with consideration of specific classes, learner characteristics, and curricular demands in contexts outside Europe.

\section{REFERENCES}

Banegas, D. L. (2012). Integrating content and language in English language teaching in secondary education: Models, benefits, and challenges. Studies in Second Language Learning and Teaching, 2(1), 111-136.

Banegas, D. L. (2013a). Teacher, what page today? A look at materials development. In A. Leceta \& R. I. Cúneo (Eds.), V Jornadas en actualización de la enseñanza del inglés (pp. 6-13). San Juan, Puerto Rico: Universidad Nacional de San Juan.

Banegas, D. L. (2013b). The integration of content and language as a driving force in the EFL lesson. In E. Ushioda (Ed.), International perspectives on motivation: Language learning and professional challenges (pp. 82-97). Basingstoke, UK: Palgrave Macmillan.

Banegas, D. L. (2013C). Teacher developing language-driven CLIL through collaborative action research in Argentina (Unpublished doctoral dissertation). University of Warwick, Coventry, UK.

Barboni, S. \& Simón, L. (2013). Designing intercultural and bilingual e-material for primary and secondary schools. In L. Renart \& D. L. Banegas (Eds.), Roots \& routes in language education: Bi-multiplurilingualism, interculturality and identity. Selected papers from the 38th FAAPI Conference (pp. 56-72). Buenos Aires, Argentina: APIBA.

Braun, E., Cabral, V. \& Cheme Arriaga, R. (2013).Materiales curriculares. Lengua extranjera: Inglés. Ciclo orientado de la educación secundaria. Santa Rosa, Argentina: Ministerio de Cultura y Educación, Gobierno de La Pampa.

Braun E. N. \& Cheme Arriaga, R. (2011). Content and language integrated learning (CLIL): Implementation at primary school level. In E. N. Braun (Ed.), Hacia una didáctica del Inglés para niños en escuelas primarias (pp. 47-60). Santa Rosa, Argentina: EdUNLPam. 
Cenoz, J. (2013a). Discussion: Towards an educational perspective in CLIL language policy and pedagogical practice. International Journal of Bilingual Education and Bilingualism, 16(3), 389-394.

Cenoz, J. (2013b, June). Integration vs. isolation: Towards a multilingual approach in CLIL.Plenary talk presented at the ALP-CLIL Conference, 5-8 June, 2013, Madrid, Spain.

Cenoz, J. (2015). Content-based instruction and content and language integrated learning: The same or different? Language, Culture and Curriculum, 28(1), 8-24.

Cenoz, J., Genesee, F., \& Gorter, D. (2014). Critical analysis of CLIL: Taking stock and looking forward. Applied Linguistics, 35(3), 243-262.

Coyle, D., Hood, P. \& Marsh, D. (2010). Content and language integrated learning. Cambridge, UK: Cambridge University Press.

Dalton-Puffer, C. (2011). Content-and-language integrated learning: From practice to principle? Annual Review of Applied Linguistics, 31(1), 182-204.

Denman, J., Tanner, R., \& de Graaff, R. (2013). CLIL in junior vocational secondary education: Challenges and opportunities for teaching and learning. International Journal of Bilingual Education and Bilingualism, 16(3), 285-300.

Garton, S., \& Graves, K. (Eds.). (2014). International perspectives on materials in ELT. Basingstoke, UK: Palgrave Macmillan.

Gray, J. (Ed.). (2013). Critical perspectives on language teaching materials. Basingstoke, UK: Palgrave Macmillan.

Gustafsson, M. (Ed.). (2011). Collaborating for content and language integrated learning. Across the Disciplines, 8(3 [Special Issue]). Retrieved from http://wac.colostate.edu/atd/clil/index.cfm

Ioannou Georgiou, S. (2012). Reviewing the puzzle of CLIL. ELT Journal, 66(4), 495-504.

Lin, A. M. Y. (2015). Conceptualising the potential role of L1 in CLIL. Language, Culture and Curriculum, 28(1), 74-89.

Llinares, A., Morton, T. \& Whittaker, R. (2012). The roles of language in CLIL. Cambridge, UK: Cambridge University Press. 
López Barrios, M., Villanueva de Debat, E. \& Tavella, G. (2008). Materials in use in Argentina and the southern cone. In B. Tomlinson (Ed.), English language learning materials (pp. 300-316). London, UK: Continuum.

Mariño Avila, C. M. (2014). Towards implementing CLIL (Content and Language Integrated Learning) at CBS (Tunja, Colombia). Colombian Applied Linguistics Journal, 16(2), 151-160.

Marsh, D. (2002). CLIL/EMILE - The European dimension: Actions, trends and foresight potential. Jyväskylä, Finland: UniCOM, Continuing Education Centre, University of Jyväskylä.

Mayring, P. (2000). Qualitative content analysis. Forum Qualitative Sozialforschung/Forum: Qualitative Social Research, 1(2). Retrieved from http://nbn-resolving.de/urn:nbn:de:0114-fqsooo2204

McGrath, I. (2013). Teaching materials and the roles of EFL/ESL teachers: Theory and practice. London, UK: Bloomsbury.

Mehisto, P. (2012). Criteria for producing CLIL learning material. Encuentro, 21, 15-33.

Moirano, M. C. (2012). Teaching the students and not the book: Addressing the problem of culture teaching in EFL in Argentina. GIST Education and Learning Research Journal, 6, 71-96.

Moore, P. \& Lorenzo, F. (2007). Adapting authentic materials for CLIL classrooms: An empirical study. Vienna English Working Papers, 16(3), 28-35.

Morton, T. (2013). Critically evaluating materials for CLIL: Practitioners' practices and perspectives. In J. Gray (Ed.), Critical perspectives on language teaching materials (pp. 111-136). Basingstoke, UK: Palgrave Macmillan.

Pérez-Cañado, M. L. (2012). CLIL research in Europe: Past, present, and future. International Journal of Bilingual Education and Bilingualism, 15(3), 315-341.

Robertson, P. \& Adamson, J. (Eds.). (2013). CLIL in Asian contexts: Emerging trends. Asian EFL Journal, 15(4).

Ruiz de Zarobe, Y. (2013). CLIL implementation: From policy-makers to individual initiatives. International Journal of Bilingual Education and Bilingualism, 16(3), 231-243. 
Ruiz de Zarobe, Y. \& Cenoz, J. (2015). Way forward in the twenty-first century in content-based instruction: Moving towards integration, Language, Culture and Curriculum, 28(1), 90-96.

Somers, T. \& Surmont, J. (2012). CLIL and immersion: How clear-cut are they? ELT Journal, 66(1), 113-116.

Tomlinson, B. (Ed.). (2013). Developing materials for language teaching ( $2^{\text {nd }}$ ed.). London, UK: Bloomsbury.

UTV Motion Pictures (2012, October 28). Kurbaan - Classroom Debate Scene - Vivek Oberoi | Saif Ali Khan [Video file]. YouTube. Retrieved from https://www.youtube.com/watch?v=8jHOQkfZT4Ow 